\title{
FLORA DE GRÃO-MOGOL, MINAS GERAIS: MEMECYLACEAE ${ }^{1}$
}

\author{
RENATO GOLDENBERG* \& ANGELA BORGES MARTINS** \\ *Departamento de Botânica, Setor de Ciências Biológicas, Universidade Federal do Paraná, \\ Caixa postal 19041, 81531-970 - Curitiba, PR, Brasil. \\ ${ }^{* *}$ Departamento de Biologia Vegetal, Instituto de Biologia, Universidade Estadual de Campinas, \\ Caixa postal 6109 - Campinas, SP, Brasil.
}

\begin{abstract}
CLAUSING, G. \& RENNER, S.S. 2001. Molecular phylogenetics of Melastomataceae and Memecylaceae: Implications for character evolution. Amer. J. Bot. 88: 486-498

COGNIAUX, A. 1888. Melastomaceae. In C.F.P. Martius, A.W. Eichler \& I. Urban (eds.) Flora brasiliensis. Frid. Fleischer. Leipzig, vol. 14, pars 4, p. 1-655, tab. 1-130.

COGNIAUX, A. 1891. Melastomataceae. In A. De Candolle \& C. De Candolle (eds.) Monographiae Phanerogamarum. Masson. Paris, vol. 7, p. 1-1256.

MORLEY, T. 1976. Memecyleae (Melastomataceae). Flora Neotropica Monographs 15: 1-295.
\end{abstract}

\section{Mouriri Aubl.}

Arbustos ou árvores geralmente glabros. Folhas sésseis ou curto-pecioladas, opostas, simples, coriáceas ou raro cartáceas, margem inteira, nervação broquidódroma, geralmente com apenas a nervura central visível e as demais levemente ou não perceptíveis. Flores raramente isoladas, ou em inflorescências em tirsos ou dicásios curtos, estes isolados ou fasciculados, axilares ou mais frequentemente ramifloras ou caulifloras. Flores (4-)-5-meras, pediceladas. Hipanto turbinado, campanulado, hemisférico ou obcônico. Cálice regularmente lobado, truncado ou fechado no botão a abrindo-se em segmentos irregulares, persistente. Pétalas geralmente brancas ou róseas, raro purpúreas ou vermelhas. Estames (8) 10, geralmente isomorfos ou subisomorfos, com filetes dobrados no botão, anteras amarelas, linear-oblongas, rimosas (com duas aberturas laterais/apicais, encurvadas), conectivo prolongado em apêndice dorso-basal arredondado ou alongado, com uma glândula dorsal, elíptica e côncava. Ovário ínfero, 1-locular com placentação central-livre ou 4-5-locular com placentação basal, estilete filiforme, ápice recurvado. Fruto bacáceo esférico, globoso ou bilobado; sementes subesféricas, às vezes com uma face plana, hilo basal arredondado ou elíptico.

1.1. Mouriri glazioviana Cogn. in Mart., Fl. bras. 14(4): 580, t. 124 , fig. 1.1888.

Arbustos 1,8-3 m alt. a árvores até $6 \mathrm{~m}$ alt. Folhas com pecíolo 1-2 mm compr.; lâmina 5-9 cm compr., 2-4,5 cm larg., coriácea, elíptica a oblongo-elíptica, arredondada na base e aguda, acuminada, obtusa ou raro arredondada no ápice, nervura central (face adaxial) plana a levemente convexa, nervuras laterais não perceptíveis ou muito tênues. Racemos isolados ou fasciculados, ramifloros ou caulifloros (quando em frutos). Flores 5-meras, com pedicelo ca. $0,4 \mathrm{~mm}$ compr. Hipanto (incluindo cálice) 6-7 $\mathrm{mm}$ compr. Cálice com lacínias 2-3 mm compr., triangulares, unidas na base em um tubo que se rompe durante a antese. Pétalas 5-5,5 mm compr., 5-5,5 mm larg., largamente ovais, acuminadas no ápice, róseas. Estames subisomorfos, tecas 2,2-3 mm compr., glândulas no conectivo 0,5-0,6 mm diâm. Ovário 4-locular, 6-8 óvulos por lóculo, estilete 11-12 mm compr. Frutos maduros não vistos (Fig. 1).

Giulietti et al. CFCR 3414 (SPF, UEC, US); Pirani et al. 906 (SPF, UEC, US); Zappi et al. CFCR 9889 e 9918 (SPF, UEC, US).

Encontrada em Goiás, Minas Gerais, Rio de Janeiro e São Paulo. Coletada com flores em abril e julho, com frutos em maio e julho. Em Grão-Mogol foi coletada em campo ru-

${ }^{1}$ Trabalho realizado conforme o planejamento apresentado por Pirani et al. (2003). Bol. Bot. Univ. São Paulo 21(1): 1-24. 
pestre e "carrascal". Os frutos são comestíveis, e as plantas recebem o nome popular de mandapuçá. Mouriri e Votomita vem tradicionalmente sendo tratados como pertencentes a uma subfamília (Memecyloideae) em Melastomataceae (Cogniaux 1888, Cogniaux 1891), mas diferem dos demais gêneros neotropicais pertencentes a esta família pela ner- vação broquidódroma e pelos estames com glândulas dorsais. Memecylaceae e Melastomataceae são grupos-irmãos (Clausing \& Renner 2001) e, portanto, o reconhecimento de uma família apenas também é possível, da mesma forma que o reconhecimento das duas famílias como entidades distintas.

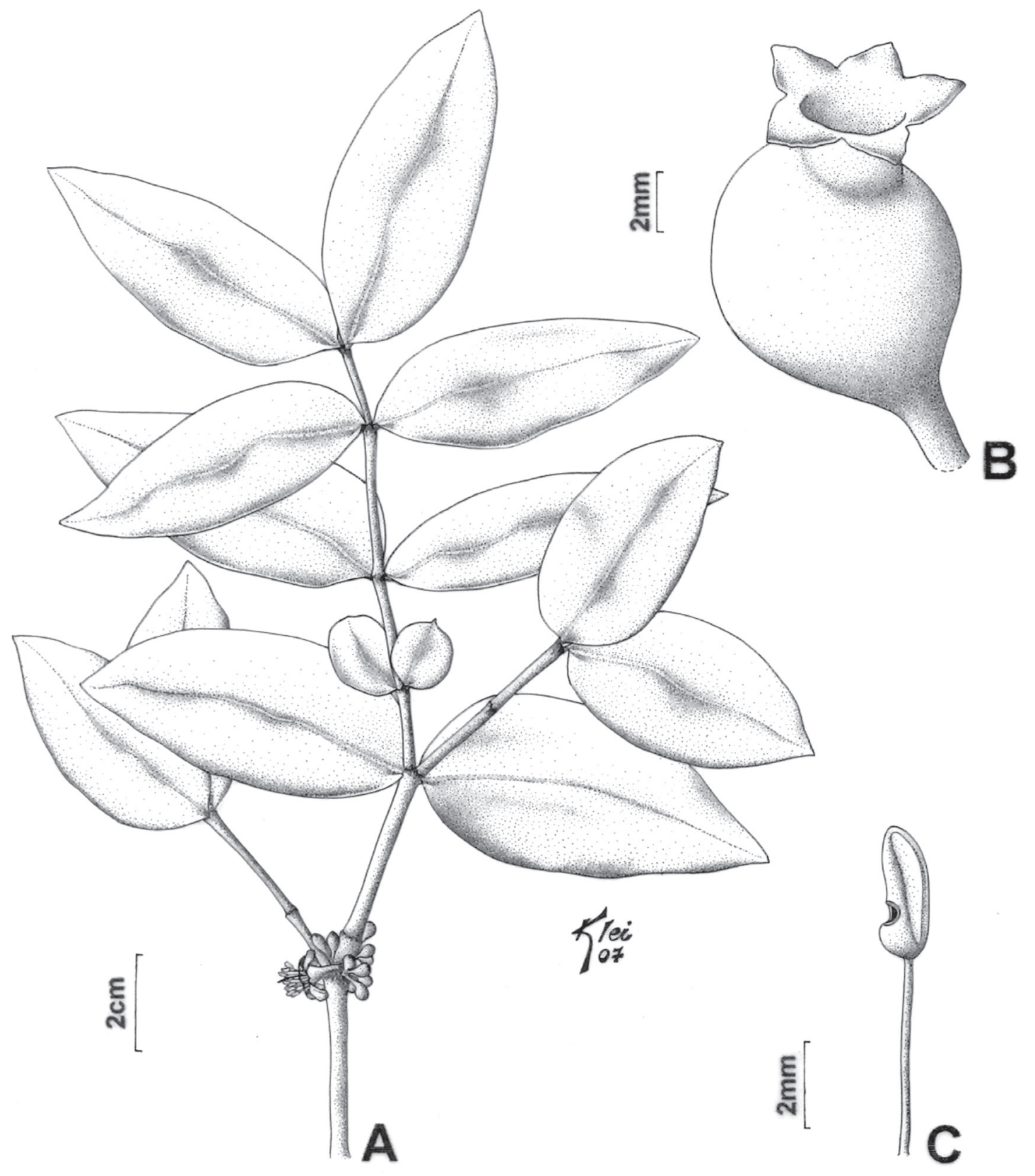

Fig. 1. MEMECYLACEAE. A-C. Mouriri glazioviana: A. Ápice do ramo; B. Fruto; C. Estame (Zappi et al. CFCR 9918). 